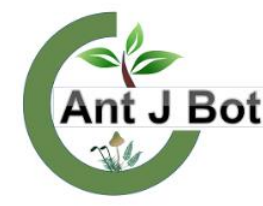

Received :22.01.2021

Accepted : 19.02.2021

Online : 24.02 .2021

\title{
In vitro effectiveness of some plant species as green manure for the control of stem and bulb nematode (Ditylenchus dipsaci)
}

\author{
Elif YAVUZASLANOĞLU ${ }^{1 *} \oplus$, Gamze AKSAY ${ }^{2} \oplus$, Ahmet ÇETINKAYA ${ }^{3} \odot$ \\ ${ }^{1}$ Karamanoğlu Mehmetbey University, Technical Sciences Vocational School, Department of Plant and Animal \\ Production, Karaman, Turkey \\ ${ }^{2,3}$ Karamanoğlu Mehmetbey University, Institute of Science, Karaman, Turkey \\ *eyavuzaslanoglu@kmu.edu.tr, ${ }^{2}$ gggamze.21@gmail.com, 3 ahmet_cetinkayaaa@hotmail.com
}

\section{Bazı bitki türlerinin yeşil gübre olarak soğan sak nematodunun (Ditylenchus dipsaci) mücadelesi için in vitro etkinliği}

\begin{abstract}
Stem and bulb nematode, Ditylenchus dipsaci (Kühn, 1857) Filipjev, 1936, is a plant parasitic nematode that causes significant losses in plant production in the world. One of the promising methods for control of soil-borne diseases and pests that do not accumulate in nature is green manure application. Studies on the effectiveness of green manure on stem and bulb nematode are limited. In this study, the activity of 4 plant species from Brassicaceae family and one Tagetes patula L. variety on stem and bulb nematode was investigated in vitro. In the study, rates of motionless nematodes were recorded in the water and sand medium in 4 days and 11 days in five plant species. The efficiency of the plant species was increased over time. In all treatments in the study, the highest rate of motionless nematodes was obtained with arugula. On the $4^{\text {th }}$ and $11^{\text {th }}$ days in the water medium, $84.1 \%$ and $95.7 \%$ of motionless nematodes were obtained, respectively, while in the sand medium, the rate of motionless nematodes was $60.2 \%$ and $86.1 \%$. Following the arugula, Tagetes patula showed activity at the rates of $72.9 \%$ and $98.3 \%$ in the water medium and $40.9 \%$ and $81.9 \%$ in the sand medium on the $4^{\text {th }}$ and $11^{\text {th }}$ days, respectively. Radish was also found promising with $62.5 \%$ and $94.2 \%$ in water medium, $59.2 \%$ and 80.9 in the sand medium, on the $4^{\text {th }}$ and $11^{\text {th }}$ days, respectively. The data obtained in the study provided preliminary data for green manure applications under field conditions.
\end{abstract}

Key words: Biofumigation, Brassicaceae, cultural management, nematode suppression, Tagetes spp.

Özet: Soğan sak nematodu, Ditylenchus dipsaci (Kühn, 1857) Filipjev, 1936, dünyada bitkisel üretimde önemli kayılara neden olan bitki paraziti bir nematoddur. Doğada birikim yapmayan ve toprak kökenli hastalık ve zararlıların kontrolünde ümitvar mücadele yöntemlerinden biri yeşil gübrelemedir. Yeşil gübrelemenin soğan sak nematodu üzerine etkinliği ile ilgili çalışmalar sınırlıdır. Bu çalışmada, Brassicaceae familyasından 4 bitki türü ve bir Tagetes patula L. çeşidinin soğan sak nematodu üzerindeki etkinliği in vitro olarak araştırılmıştır. Çalışmada su ve kum ortamında 4. ve 11. günde 5 bitki türünde nematodlardaki hareketsizlik oranları kayıt edilmiştir. Bitki türlerinin etkinliği zamanla artmıştır. Çalışmada bütün uygulamalarda en yüksek hareketsiz nematod oranı roka ile elde edilmiştir. Su ortamında 4. ve 11. günlerde sırasıyla \%84.1 ve $\% 95.7$ oranlarında hareketsiz nematod elde edilirken kum ortamında, hareketsiz nematod oran $1 \% 60.2$ ve \%86.1 olarak kayıt edilmiştir. Rokayı takiben Tagetes patula 4. ve 11. günlerde sırasıyla su ortamında $\% 72.9$ ve $\% 98.3$ oranlarında, kum ortamında ise $\% 40.9$ ve $\% 81.9$ oranlarında etkinlik göstermiştir. Turpta sırasıyla 4 . ve 11 . günlerde su ortamında $\% 62.5$ ve $\% 94.2$, kum ortamında \%59.2 ve \%80.9 hareketsiz nematod oranları ile ümitvar bulunmuștur. Calışmada elde edilen veriler tarla koşullarında yeşil gübre uygulamaları için ön veri oluşturmuş̧ur.

Anahtar Kelimeler: Biyofumigasyon, Brassicaceae, kültürel mücadele, nematod baskılanması, Tagetes spp.

Citation: Yavuzaslanoğlu E, Aksay G, Çetinkaya A (2021). In vitro effectiveness of some plant species as green manure for the control of stem and bulb nematode (Ditylenchus dipsaci). Anatolian Journal of Botany 5(1): 32-36.

\section{Introduction}

Nematoda filum of the animal kingdom include plant parasitic microscopic round worms. The plant parasitic nematode species that causes the most economic losses in the $4^{\text {th }}$ place in the world is stem and bulb nematode (Ditylenchus dipsaci (Kühn, 1857) Filipjev, 1936 (AbdElgawad and Askary, 2015). Stem and bulb nematode is distributed all over the world, parasites more than 500 plant species and causes yield losses economically (Sturhan and Brzeski, 1991).

The economic damage threshold of the stem and bulb nematode is very low. It has been reported that serious damages occur on plant production when 10 nematodes are found in $500 \mathrm{~g}$ soil (Seinhorst, 1956). It is necessary to control the nematode by applying an integrated control strategy in order to continue plant production economically. It is very important for soil sustainability to prioritize cultural and biological control practices such as rotation practices with non-host plant species, growing resistant varieties, use of nematode suppressive plant species and green manure practices in integrated control practices.

Stem and bulb nematode lives in the intercellular parts on the above-ground organs of the plant, damaging the plant. Systemically effective chemicals which are necessary for killing the nematode in plant tissue are very toxic to humans and other organisms in the environment. Their use under field conditions is not economical. For this reason, it is recommended to use of chemicals as soil fumigation for chemical control of nematodes. However, since the synthetic chemicals used are not natural, it is possible that they cause biological accumulation in biological organisms and chronic poisoning. For this reason, plant species with biofumigant effect that naturally decompose and do not leave residues in the soil constitute an important alternative source for the control of nematodes. Effectiveness of plant species such as radish (Raphanus sativus L.), arugula (Eruca sativa Mill.), broccoli (Brassica oleraceae L.), canola (Brassica napus L.) and 
mustard (Brassica juncea Czern.), from the Brassicaceae family, on nematode control have been found to be high, mostly for Meloidogyne spp. (Johnson et al., 1992; Mojtahedi et al., 1993; Al-Rehiayani and Hafez, 1998; Potter et al., 1998; Stapleton and Duncan, 1998; McLeod and Steel, 1999; Melakeberhan et al., 2006; Kaşkavalcı et al., 2009; Youssef and Lashein, 2013; Kruger et al., 2015).

Out of the Brassicaceae family, Tagetes spp., has become a highly emphasized plant as green manure to plant parasitic nematodes, especially for the suppressive effects on Meloidogyne spp. (Kimpinski et al., 2000; Evenhuis et al., 2004; Seigies and Pritts, 2006; Kaşkavalcı et al., 2009).

Among the plant parasitic nematodes, the most studied nematode species are root knot nematodes (Meloidogyne spp.), which are the most economically important nematodes in the world. There are limited studies on the control of stem and bulb nematode using biofumigant plant species in the world. No study was found in Turkey. With this purpose, it is aimed to determine the in vitro activities of different plant species for the usage as green manure in plant production areas where stem and bulb nematode is infested.

\section{Materials and method}

\subsection{Plant materials}

Totally 4 plant species of broccoli (Brassica oleraceae var. botrytis L. cv. Standard, Intfa Seed, Konya),cabbage (B. oleraceae var. capitata L. cv. Standard, Intfa Seed, Konya), radish (Raphanus sativus L. cv. Standard, Intfa Seed, Konya) and arugula (Eruca sativa Mill. cv. Standard, Intfa Seed, Konya) from Brassicaceae family and a marigold species (Tagetes patula L. cv. Bonanza, Harmony, Tasaco Agriculture, Antalya) were investigated for in vitro effectiveness as green manure against $D$. dipsaci.

\subsection{Nematode inoculums}

Pure culture of nematode was used in the study. Nematodes were originally isolated from garlic samples in Karaman Province, Central District in Central Anatolian Plateau (N: 37.10351 E: 33.117). Nematode culture was maintained on sterile carrot discs at $20{ }^{\circ} \mathrm{C}$ in dark (Yavuzaslanoglu and Aksay, 2021). Nematodes for the experiment were extracted from two months old sterile carrot disc cultures by washing the surface of the carrot discs with sterile tap water. The nematode suspension was then concentrated to the volume including 400 nematodes in $10 \mu 1$ to use in each individual replication.

\subsection{Experimental design and treatments}

Sterile plastic petri dishes (60 $\mathrm{mm}$ diameter) were used in the study. The experiment was established according to the factorial completely randomized plot design. There were three factors in the experiment: experiment medium, incubation time and plant species. In sand medium treatments, petri dishes included $10 \mathrm{~g}$ sterile sand moistened with $2 \mathrm{ml}$ of sterile water. However, in water medium treatments, the petri dishes included $4 \mathrm{ml}$ sterile tap water (Oka et al., 2012). Petri dishes were incubated for 4 days and 11 days.

The leaves of the plant materials were frozen at $-80{ }^{\circ} \mathrm{C}$ overnight, grinded by hand in plastic bag and $2 \mathrm{~g}$ of powdered plant materials was added to the petri dishes (Oka et al., 2012). Immediately afterwards 400 nematodes in $10 \mu \mathrm{l}$ water were inoculated to all petri dishes. A negative control without plant material was included in each time and medium treatments. Each treatment had 5 replicates and experiment was repeated once again in same conditions. Petri dishes were incubated at $20{ }^{\circ} \mathrm{C}$ at dark during experiment.

The mobiled nematodes were extracted from all petri dishes using "Modified Baermann Funnel" technique for 24 hours (Hooper et al., 2005). Obtained nematode suspension was then concentrated to $1 \mathrm{ml}$. The nematode numbers were counted in whole sample under light microscope at 10x magnification. Living nematodes were obtained with extraction technique (Hooper et al., 2005). The number of motionless nematodes was determined by subtracting the number of motile nematodes obtained in each petri dish from the initial number of 400 nematodes. The motionless nematodes per treatment was calculated and presented as percent (\%) (Aydınlı et al., 2019).

\subsection{Statistical analysis}

Data of percent motionless nematodes per petri dish was analyzed according to fit model of completely randomized plot design with four factors. In addition to three factors investigated in the experiment, repetition of the experiment was included as a factor to the statistical analysis. Effect of factors and their interactions were investigated. Analysis of variance (ANOVA), Tukey HSD test and Student's t test were used for determination of statistically significant differences among treatments and their interactions. Statistical analyses were performed using JMP ${ }^{\odot} 5.0$ software (JMP, 2020).

\section{Results}

The number of motionless nematodes (\%) obtained was not statistically different in the two experiments performed. Therefore, the data obtained from two experiments were combined and evaluated. While the number of nematodes in the two different media examined in the experiment did not differ statistically, the number of motionless nematodes on the $4^{\text {th }}$ and $11^{\text {th }}$ days in the experiment showed a statistically significant difference $(\mathrm{P}$ $<0.05)$.

In the experiment, no statistically significant interaction was found between the experiment medium and the incubation time. The rates of motionless nematodes at plant species treatments in the experiment in sand and water medium as green fertilizer were statistically different $(\mathrm{P}<0.05)$. The interaction of plant species with experiment medium and the incubation time was also found to be statistically significant $(\mathrm{P}<0.05)$.

On $4^{\text {th }}$ day in the water medium, the lowest number of immobile nematodes was obtained in negative control $(9.6 \%)$. The rate of motionless nematodes obtained in the all plant species was found to be statistically higher than the negative control $(\mathrm{P}<0.05)$. Among the plant treatments, the lowest rates of motionless nematodes were recorded in cabbage and broccoli plant species at 38.5\% and $46.9 \%$, respectively. These plant species were found to have statistically significantly lower motionless nematode rates than of the radish, arugula and marigold in the experiment. The highest rate of motionless nematodes 
was obtained with arugula $(84.1 \%)$. Subsequently, $72.9 \%$ in marigold and $62.5 \%$ in radish were obtained (Table 1).

The rate of motionless nematodes on the $11^{\text {th }}$ day in the water medium did not show a statistically significant difference between plant species, while the control treatment was significantly lower $(24.9 \%)$ than all plant species treatments. The highest rates of motionless nematodes on the $11^{\text {th }}$ day in the water medium, as on the $4^{\text {th }}$ day, were obtained in marigold $(98.3 \%)$, arugula $(95.7 \%)$ and radish $(94.2 \%)$ treatments. It was recorded as $90.2 \%$ and $92.6 \%$ in cabbage and broccoli treatments, respectively (Table 1).

The rates of motionless nematodes obtained on the $11^{\text {th }}$ day in the water medium were significantly higher than the $4^{\text {th }}$ day in all plant treatments but not negative control treatment.

Table 1. Percentage of motionless nematodes (Ditylenchus dipsaci) in plant treatments at water medium with 4 and 11 days incubation times.

\begin{tabular}{|l|c|c|}
\hline Plant Treatments & $\begin{array}{c}\text { 4 days } \\
\text { incubation }\end{array}$ & $\begin{array}{c}\text { 11 days } \\
\text { incubation }\end{array}$ \\
\hline $\begin{array}{l}\text { Broccoli (Brassica oleraceae } \\
\text { var. } \text { botrytis } \text { L. cv. Standard) }\end{array}$ & $46.9 \pm 2.9 \mathrm{cB}$ & $92.6 \pm 3.1 \mathrm{aA}$ \\
\hline $\begin{array}{l}\text { Cabbage } \text { (B. } \text { oleraceae } \text { var. } \\
\text { capitata } \text { L. cv. Standard) }\end{array}$ & $38.5 \pm 2.9 \mathrm{cB}$ & $90.2 \pm 3.1 \mathrm{aA}$ \\
\hline $\begin{array}{l}\text { Radish (Raphanus sativus } \mathrm{L} . \\
\text { cv. Standard) }\end{array}$ & $62.5 \pm 3.1 \mathrm{bB}$ & $94.2 \pm 3.1 \mathrm{aA}$ \\
\hline $\begin{array}{l}\text { Arugula (Eruca sativa Mill. cv. } \\
\text { Standard) }\end{array}$ & $84.1 \pm 2.9 \mathrm{aB}$ & $95.7 \pm 3.1 \mathrm{aA}$ \\
\hline $\begin{array}{l}\text { Marigold (Tagetes patula } \text { L. } \\
\text { cv. Bonanza, Harmony) }\end{array}$ & $72.9 \pm 2.9 \mathrm{abB}$ & $98.3 \pm 3.4 \mathrm{aA}$ \\
\hline Negative Control & $9.6 \pm 3.1 \mathrm{dA}$ & $24.9 \pm 3.9 \mathrm{bA}$ \\
\hline
\end{tabular}

Values are means \pm standart error of 10 replicates. Means within a column followed by different lower case letters for each plant treatment are significantly different according to Tukey HSD test at $\mathrm{P}<0.05$. Means within a row followed by different capital letters for each incubation time are significantly different according to Student's t test at $\mathrm{P}<0.05$.

No statistically significant difference was found among the plant and negative control treatments on the 4th day in sand medium. While the rate of motionless nematodes in negative control was $39.1 \%$, it was recorded as 40.9, 52.0, $59.2,60.2$ and $64.4 \%$ in marigold, broccoli, radish, arugula and cabbage plant species, respectively (Table 2).

On the $11^{\text {th }}$ day of the experiment in the sand medium, the lowest statistically significant rate of motionless nematodes was obtained in negative control treatment $(62.1 \%)$. Although there is no statistical difference among plant treatments, the highest rate of motionless nematodes was obtained in arugula plant species $(86.1 \%)$, followed by marigold and radish plant species at $81.9 \%$ and $80.9 \%$, respectively. On the other hand, $80.6 \%$ and $77.3 \%$ motionless nematodes were obtained in cabbage and broccoli treatments, respectively (Table 2).

The rate of motionless nematodes in all plant treatments and negative control in the sand medium was found to be statistically significantly higher on the 11th day than on the 4th day (Table 2).

\section{Discussions}

In vitro suppression efficacy of potential green manure plants, which is a promising tool for controlling soil-borne pathogens and nematodes without accumulation in nature, for the control of stem and bulb nematode, which is common in onion and garlic growing areas in our country was investigated. The study provided preliminary data useful for determining the plant species for field experiments.

Table 2. Percentage of motionless nematodes (Ditylenchus dipsaci) in plant treatments at sand medium with 4 and 11 days incubation times.

\begin{tabular}{|l|c|c|}
\hline Plant Treatments & $\begin{array}{c}\text { 4 days } \\
\text { incubation }\end{array}$ & $\begin{array}{c}\text { 11 days } \\
\text { incubation }\end{array}$ \\
\hline $\begin{array}{l}\text { Broccoli (Brassica oleraceae } \\
\text { var. botrytis L. cv. Standard) }\end{array}$ & $52.0 \pm 6.1 \mathrm{aB}$ & $77.3 \pm 3.4 \mathrm{abA}$ \\
\hline $\begin{array}{l}\text { Cabbage (B. oleraceae var. } \\
\text { capitata L. cv. Standard) }\end{array}$ & $64.4 \pm 61 \mathrm{aB}$ & $80.6 \pm 3.4 \mathrm{aA}$ \\
\hline $\begin{array}{l}\text { Radish (Raphanus sativus } \mathrm{L} . \\
\text { cv. Standard) }\end{array}$ & $59.2 \pm 6.1 \mathrm{aB}$ & $80.9 \pm 3.4 \mathrm{aA}$ \\
\hline $\begin{array}{l}\text { Arugula (Eruca sativa Mill. } \\
\text { cv. Standard) }\end{array}$ & $60.2 \pm 6.1 \mathrm{aB}$ & $86.1 \pm 3.6 \mathrm{aA}$ \\
\hline $\begin{array}{l}\text { Marigold (Tagetes patula } \mathrm{L} . \\
\text { cv. Bonanza, Harmony) }\end{array}$ & $40.9 \pm 6.1 \mathrm{aB}$ & $81.9 \pm 3.4 \mathrm{aA}$ \\
\hline Negative Control & $39.1 \pm 7.2 \mathrm{aB}$ & $62.1 \pm 3.8 \mathrm{bA}$ \\
\hline
\end{tabular}

Values are means \pm standart error of 10 replicates. Means within a column followed by different lower case letters for each plant treatment are significantly different according to Tukey HSD test at $\mathrm{P}<0.05$. Means within a row followed by different capital letters for each incubation time are significantly different according to Student's $t$ test at $\mathrm{P}<0.05$.

It is stated that one of the most important environmental factors for the high suppression efficiency of plants under field conditions is the moisture content in the soil during application. Water plays a critical role in the activity of myrosinase enzyme, which is necessary for the formation of suppressive isothiocyanate compounds (Matthiessen and Kirkegaard, 2006). In the study carried out, obtaining suppression efficiency higher in water medium, even it was not statistically significant, once again revealed that the water is important factor for myrosinase enzyme activity and biofumigation action.

In the experiment, arugula was the plant species with the highest efficiency in both water and sand mediums. In a study conducted under greenhouse conditions, arugula as applied green manure in soil reduced the populations of Meloidogyne hapla Chitwood 1949 and M. chitwoodi Golden et al. 1980 and Paratrichodorus allius Jensen, 1963 up to $99 \%$ (Riga, 2011). Similar effects have been recorded against root knot nematodes by Kruger et al. (2015).

Radish, which caused a high rate of motionless nematodes in the current experiment, has also been shown to be highly effective on other plant parasitic nematodes. It has been determined by different studies that the potato cyst nematode Globodera pallida Stone, 1973 second-stage larvae and cyst populations had been decreased by radish green manure application (Lord et al., 2011; Ngala et al., 2015). Similarly, higher effects of this plant as green manure has been found on $M$. citwoodi nematode population (Hafez and Sundararaj, 2000).

Other than the Brassicaceae family, one of the most promising plant species with the suppression effect is the Tagetes species that was shown in our study as well. Seigies and Pritts (2006) reported that after rotation with $T$. erecta in strawberry plantations, the number of nematodes decreased, the roots of the plants became 
stronger and fruit yield increased. In a study conducted in Canada, it was determined that tuber yield increased and $P$. penetrans population density decreased in potato cultivation after rotation using Tagetes species (Kimpinski et al., 2000). In organic tomato cultivation, it was determined that there is a decrease in galls formed on the roots in infested soil with $M$. incognita during the autumn period in the co-cultivation with T.erecta (Kaşkavalc1 et al., 2009). It is recommended to wait 7-10 days until the cultivation after the incorporation of suppressive plant species under field conditions in order to fully realize the biofumigation activity (Youssef, 2015). In our study, high efficiency rates with plant species in water and sand medium were obtained on the $11^{\text {th }}$ day of the experiment and it was found that it increased depending on time.

A significant contribution has been made to the literature on the control of stem and bulb nematode using green manure application. In the next stage of the study, we will focus on the efficacy of promising plant species identified in the current study under field conditions.

\section{Conflict of Interest}

Authors have declared no conflict of interest.

\section{Authors' Contributions}

The authors contributed equally.

\section{References}

Abd-Elgawad MMM, Askary TH (2015). Impact of phytonematodes on agriculture ecology. In: Askary TH, Martinelli PRP (eds.). Biocontrol Agents of Phytonematodes. London: CAB International.

Al-Rehiayani S, Hafez S (1998). Host status and greend manure effect of selected crops on Meloidogne chitwodi race 2 and Pratylenchus neglectus. Nematropica 28: 213-230.

Aydınlı G, Şen F, Mennan S (2019). Bazı bitki ekstraktlarının kök-ur nematodu Meloidogyne arenaria (Neal, 1889) Chitwood, 1949 (Tylenchida: Meloidogynidae)'nın kontrolünde kullanılabilme potansiyeli. KSÜ Tarım ve Doğa Dergisi 22(3): 414420.

Evenhuis A, Korthals GV, Molendijk LPG (2004). Tagetes patula as an effective catch crop for long-term control of Pratylenchus penetrans. Nematology 6: 877-881.

Johnson AW, Golden AM, Auld DL, Summer DR (1992). Effects of rapeseed and vetch as green manure crops and fallow on nematodes and soilborne pathogens. Journal of Nematology 24: 117-126.

JMP (2020). Statistics Website: https://www.jmp.com [Accessed: 19 January 2021].

Hafez SL, Sundararaj P (2000). Evaluation of chemical strategies along with cultural practices for the management of Meloidogyne chitwoodi on potato. International Journal of Nematology 10: 89-93.

Hooper DJ, Hallmann J, Subbotin SA (2005). Methods for Extraction, Processing and Detection of Plant and Soil Nematodes. In: Luc M, Sikora RA, Bridge J (eds.). Plant Parasitic Nematodes in Subtropical and Tropical Agriculture. London: CABI Publishing. pp. 87-119.

Kaşkavalcı G, Tüzel Y, Dura O, Öztekin GB (2009). Effects of alternative control methods against Meloidogyne incognita in organic tomato production. Ekoloji 72: 23-31.

Kimpinski JW, Arsenault J, Gallant CE, Sanderson JB (2000). The effect of marigolds (Tagetes spp.) and other cover crops on Pratylenchus penetrans and on following potato crops. Supplemental Journal of Nematology 32: 531-536.

Kruger DHM, Fourie JC, Malan A (2015). Control potential of Brassicaceae cover crops as green manure and their host status for Meloidogyne javanica and Criconemoides xenoplax. South African Journal for Enology and Viticulture 36(1): 165-174.

Lord JS, Lazzeri L, Atkinson HJ, Urwin PE (2011). Biofumigation for control of pale potato cyst nematodes: activity of Brassica leaf extracts and green manures on Globodera pallida in vitro and in soil. Journal of Agricultural and Food Chemistry 59(14): 7882-7890.

Matthiessen JN, Kirkegaard JA (2006). Biofumigation and enhanced biodegradation: Oppotununity and challenge in soilborne pest and disease management. Critical Reviews in Plant Sciences 25: 235-265.

McLeod RW, Steel CC (1999). Effects of brassica-leaf gren manures and crops on activity and reproduction of Meloidogyne javanica. Nematology 1: 613-624.

Melakeberhan H, Xu A, Kravchenko A, Mennan S, Riga E (2006). Potential use of arugula (Eruca sativa L.) as a trap crop for Meloidogyne hapla. Nematology 8(5):793-799.

Mojtahedi H, Santo GS, Wilson JH, Hang AN (1993). Managing Meloidogyne chitwoodi on potato with rapeseed as gren manure. Plant Disease 77: 42-46.

Ngala BM, Haydock PPJ, Woods S, Back MA (2015). Biofumigation with Brassica juncea, Raphanus sativus and Eruca sativa for the management of field populations of the potato cyst nematode Globodera pallida. Pest Management Science 71(5): 759-769.

Oka Y, Ben-Daniel B, Cohen Y (2012). Nematicidal activity of the leaf powder and extracts of Myrtus communis to the root knot nematode Meloidogyne javanica. Plant Pathology 61: 1012-1020.

Potter MJ, Davies AJ, Rathjen AJ (1998). Suppressive impact of glucosinolates in Brassica vegetative tissues on root lesion nematode Pratylenchus neglectus. Journal of Chemical Ecology 24: 67-80.

Riga E (2011). The effects of Brassica green manures on plant parasitic and living nematodes used in combination with reduced rates of synthetic nematisides. Journal of Nematology 43(2): 119-121. 
Seigies AT, Pritts M (2006). Cover crop rotations alter soil microbiology and reduce replant disorders in strawberry. Hortscience 41: 1303-1308.

Seinhorst JW (1956). Population studies on stem eelworm Ditylenchus dipsaci. Nematologica 1: 159-164.

Stapleton JJ, Duncan RA (1998). Soil disinfestation with cruciferous amendments and sublethal heating: effects on Meloidogyne incognita, Sclerotium rotfsii and Pythium ultimum. Plant Pathology 47: 737-742.

Sturhan D, Brzeski MW (1991). Stem and bulb nematodes, Ditylenchus spp.. In: Nickle WR (ed.). Manual of agricultural nematology. New York: Marcel Dekker Publications.

Yavuzaslanoglu E, Aksay G (2021). Susceptibility of different plant species to two populations of Ditylenchus dipsaci Kühn, 1857 (Tylenchida: Anguinidae) from Turkey. Turkish Journal of Entomology 45(1): 77-86.

Youssef MMA (2015). Biofumigation as a promising tool for managing plant parasitic nematodes, a review. Scientia Agriculturae 10(3): 115-118.

Youssef MMA, Lashein AMS (2013). Effect of cabbage (Brassica oleraceae) leaf residue as a biofumigant, on root-knot nematode Meloidogyne incognita infecting tomato. Journal of Plant Protection Resources 53(3): 271-274. 